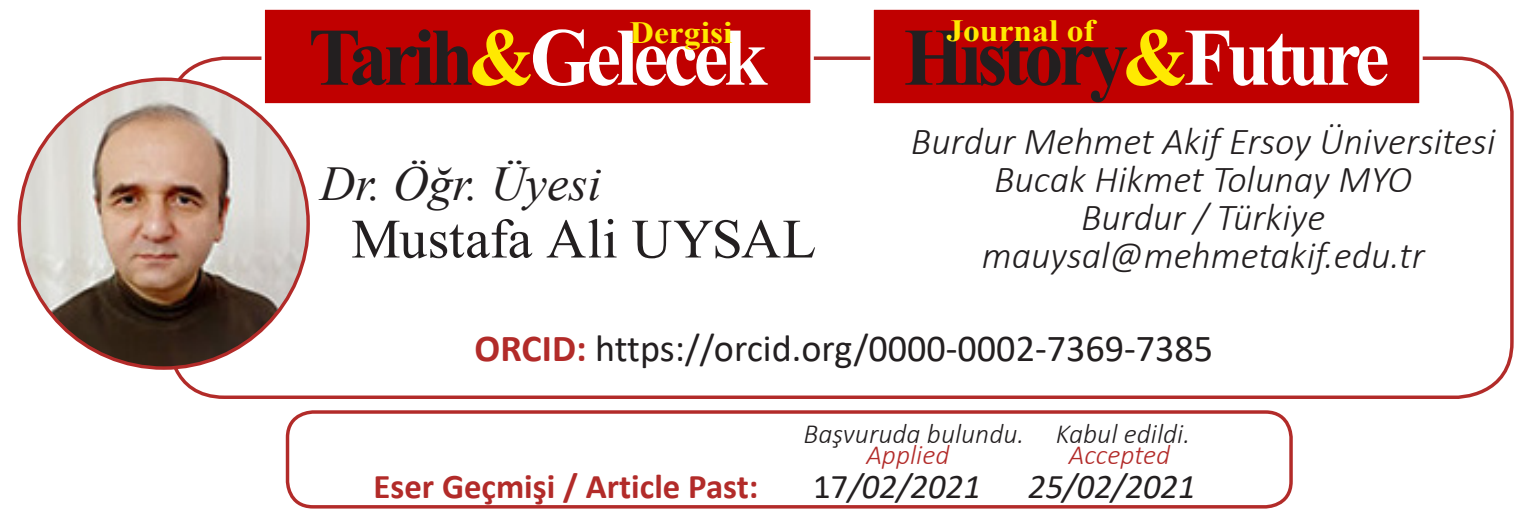

Araştırma Makalesi

DOI: http://dx.doi.org/10.21551/jhf.881797

Research Paper

Orjinal Makale / Orginal Paper

\title{
Türkiye Cumhuriyeti Devlet Salnamelerine Göre Burdur Vilayetinin Ekonomik Yapısı (1925-1929)
}

\author{
According to the Republic of Turkey Annually, Economic Structure ff \\ Burdur Province (1925-1929)
}

$\ddot{\mathrm{O} z}$

Salnameler (yıllıklar), özellikle şehir tarihi çalışmaları için en önemli kaynaklardan birisidir. Cumhuriyet döneminde yayınlanan ilk devlet salnameleri de, Osmanlı döneminde yayınlanan devlet salnameleri ve vilayet salnameleri gibi vilayetlerin idari, coğrafi, sosyal ve ekonomik yapısına dair bilgiler vermektedir. 1925-1929 yilları arasında yayınlanan devlet salnamelerinden yararlanarak Burdur şehir tarihinin bir bölümünü aydınlatabilme düşüncesi bizi bu araştırmayı yapmaya yöneltmiştir. 1926, 1927 ve 1928 yıllarında "Türkiye Cumhuriyeti Devlet Salnamesi” adıyla Osmanlica olarak yayınlanan devlet salnamelerinde ve 1929 yılında "Türkiye Cumhuriyeti Devlet Yıllığı” adıyla Latin harfleriyle yayınlanan devlet yıllığında Burdur vilayetinin coğrafi, idari, sosyal ve ekonomik yapısı hakkında ayrıntılı bilgilere yer verilmiştir. Bu çalışmada 1925-1929 yılları arasında Burdur vilayeti ve kazalarındaki tarım, hayvancılık, madencilik, dokumacılık faaliyetleri ile fabrikaları, yolları ve gelirleri hakkında istatistiki bilgiler sunulmuştur. Türkiye Cumhuriyeti Devlet Salnamelerinin yanında Konya Vilayet Salnameleri, 1927 Umumi Nüfus Tahriri ve diğer araştırma eserlere de yer verilmiştir. Bu kaynaklar incelendiği zaman Burdur'un ekonomisinin genel olarak tarım ve hayvancılığa dayandığı görülecektir.

Anahtar Kelimeler: Burdur, Vilayet, Salname, Ekonomik Yap1, Tarım.

\begin{abstract}
Annuals are one of the most important sources especially for city history studies. The first state yearbooks published in the Republican period also provide information about the administrative, geographical, social and economic structure of the provinces, such as the state yearbooks and provincial yearbooks published in the Ottoman period. The idea of enlightening a part of Burdur city history using the state annuals published between 1925-1929 has led us to do this research. In 1926, 1927 and 1928, in the
\end{abstract}


state annuals as published in Ottoman Turkish with the name of "the Republic of Turkey annual" and in 1929, in the state annuals as published in Latin alphabet with the name of "The Republic of Turkey Annual" detailed information is provided about the geographical, administrative and social structure of Burdur province. In this study, statistical information about agriculture, animal husbandry, mining, weaving activities, factories, roads and incomes in Burdur province and its districts between 1925-1929 are presented. In addition, Konya Provincial Annuals, 1927 General Population Census and other research works are also included.

Keywords: Burdur, Province, Annual, Economic Structure, Agriculture.

\section{Giriş}

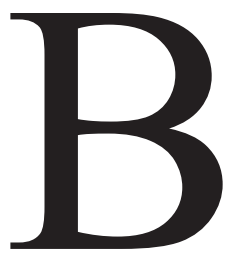

ir yıl içinde yaşanmış olan olayları özet olarak anlatmak için her yıl düzenlenen eserlere salname denir. Sal; y1l, sene anlamına gelirken, nâme; mektup, kitap anlamında kullanılmaktadır ${ }^{1}$. Salnamenin günümüzdeki karşılığ́1 yıllık kelimesidir ${ }^{2}$. Salnamelerde, vilayetlerin idari, coğrafi, sosyal ve ekonomik yapıları ve tarihleri hakkında sağlıklı ve son derece zengin bilgiler verilmektedir ${ }^{3}$.

İlk resmî salname Sadrazam Mustafa Reşit Paşa’nın teşviki ile 1847 (H. 1263) yılında Ahmed Vefik Paşa tarafindan hazırlanmış ve Salname-i Devlet-i Aliyye-i Osmaniyye adı ile yayınlanmıştır ${ }^{4}$. Devlet salnameleri, devlet teşkilatı hakkında ayrıntılı bilgi vermektedir. Bunun yanında vilayetlerde ve kazalarda görev yapan memurlar hakkında da bilgiler bulunmaktadır ${ }^{5}$.

Devlet Salnamelerinin yanında Askerî Salnameler, Bahriye Salnameleri, Hariciye Salnameleri, İlmiye Salnameleri, Maârif Salnameleri ve Vilayet Salnameleri gibi salnameler de yayınlanmıştır. Toplam 68 adet olan Devlet salnameleri, 1912 (R. 1328) y1lına kadar kesintisiz olarak yayınlanmış olup, 1918 (R. 1334) yılında ise son nüshası yayınlanmıştır. Cumhuriyet döneminde ise Devlet salnameleri 1926, 1927 ve 1928 y1llarında Arap harfleriyle, 1929 yılında Latin harfleriyle basılmışıır ${ }^{6}$. Bir yıl öncesine ait bilgiler esas alınarak hazırlanan bu salnameler, vilayetler hakkında çok değerli istatistiki bilgiler sunmaktadır.

1 Midhat Sertoğlu, Osmanlı Tarih Lûgatı, Enderun Kitabevi Yay., İstanbul 1986, s. 297.

2 Ferit Devellioğlu, Osmanlıca-Türkçe Ansiklopedik Lûgat, Aydın Kitabevi Yayınları, Ankara 1990, s. 1100.

3 Ahmet Zeki İzgöer, "Osmanlı Salnâmelerinin Şehir Tarihi Bakımından Önemi”, Türkiye Araştırmaları Literatür Dergisi, C. 3, S. 6, 2005, s. 539.

4 Bilgin Aydın, "Salname”, TDVİA, C. 36, Türkiye Diyanet Vakfı Yay. İstanbul 2009, s. 52; "Salname”, İA, C. X, Milli Eğitim Bakanlığı Yay., İstanbul 1949, s. 134-135; Tevfik Sütçü, "Sosyal Bilimlerde Araştırma Kaynağı Olarak Almanaklar, Sâlnâmeler ve Yıllıklar”, İlmi Araştırmalar, S. 18, 2004, s. 84.

5 Tevfik Sütçü, a.g.m., s. 85-86; Mehmet Zeki Pakalın, Osmanlı Tarih Deyimleri ve Terimleri Sözlüğ̈̈, C. III, Milli Eğitim Bakanlığı Yayınları, İstanbul 1971, s. 106.

6 Mustafa Ali Uysal, Salnamelere Göre Burdur (1868-1914), Libra Kitapç1lık ve Yayıncılık, İstanbul 2020, s. 18-19; Bilgin Aydın, a.g.m., s. 52; Midhat Sertoğlu, a.g.e., s. 298-299; http://ktp.isam.org.tr/salname/ savilar.php?sidno=D02467 (Erişim Tarihi: 27.02.2020). 
Bu çalışmada 1926, 1927, 1928 yıllarına ait devlet salnameleri ve 1929 yılına ait devlet yıllığından yararlanarak Burdur vilayetinin ekonomik yapısı hakkında bilgi verilmeye çalışılmıştır.

Burdur'un coğrafi sınırları hakkında en ayrıntılı bilgi 1928 yılı devlet salnamesinde verilmiştir. Buna göre, doğuda Isparta vilayetinin Eğirdir kazası, batıda Denizli vilayetinin Garbî Karaağaç kazası, kuzeyde Isparta vilayeti, güneyde Antalya vilayetinin Korkud ili kazalarıyla sınırlanmış olan Burdur vilayetinin yüzölçümü $7.500 \mathrm{~km}^{2} \operatorname{dir}^{7}$.

Burdur vilayetinin tarihi hakkında 1927 yılı devlet salnamesinde şu bilgiler verilmektedir: Cengiz'in zulmünden bıkmış olarak batıya doğru göçe mecbur olanlar arasında Kınalı Aşireti adıyla bilinen bir aşiret gelip bu havaliye yaylak ve şimdiki Cami-i Kebir'in (Ulu Cami) bulunduğu yeri pazar edinerek, Burdur'a adı geçen aşiret tarafından ilk önce Alan Pazarı ismi verilmiştir. Bir süre sonra bu pazar vesilesiyle kendilerini sabit bir yurt etrafinda toplamak ihtiyacını hisseden aşiret fertleri, önce Dört Ayetli Tekkesi ile Hamambendi civarında yerleşmişlerse de dağlardan inen suların istila ve hücumundan rahat edemeyerek Karasenir, Hac1 Ahmed, Divanbaba, Yenice mahallelerini kurmuşlar ve Karakaya mahallesini de bu sırada meydana getirmişlerdir. Çeşmebaş1 Pınarı'nın üzerindeki çifte hatlı kitâbesinden adı geçen çeşmenin hicri 907 (M. 1501) tarihinde Korkut'un doktoru Ali bin Hamza tarafından imar edildiği anlaşıldığına göre Burdur'un bu tarihten çok önce kurulmuş bir memleket olduğuna kanaat getirmek zorunlu görünüyor. Aşiret fertleri henüz Dört Ayetli Tekkesi mevkiinden yeni oluşturulan mahallelere taşınmadan önce bir aralık Tirkemiş adını taşıyan kasabanın civarına firar eden Korkud'u kovalayan takip kumandanının "Sultan Nerede?" sorusuna cevaben ahalinin "Buradadır" sözünden değiştirilmiş olarak kasabanın sonradan Burdur ismiyle şöhret bulduğu da rivayet edilmektedir.

Murad Hüdavendigar ve Yıldırım Bayezid dönemlerinde Teke ve Hamid İli ile buralara bağlı yerlerin Osmanlı Devleti'ne katılması sırasında Teke veya Hamid İli'ne bağlı olduğu kuvvetle muhtemel olan Burdur ve çevresi, o tarihten sonra Osmanlıların idaresi altına geçmiştir. Burdur, Miladî 1844 yılından 1871 yılına kadar 27 yıl kaza, 1871'den 1920 yılına kadar 49 yıl Konya vilayetine bağlı sancak ve 1920'den 1923 yılına kadar 3 yıl bağımsız liva olarak idare olunduktan sonra 1923 yılında il adını almıştır ${ }^{8}$.

1928 yılı devlet salnamesine göre Burdur vilayeti, Burdur merkez kazasılla Tefenni ve Bucak (Oğuzhan) kazalarından meydana gelmektedir. Merkez kazaya bağlı Sertaç (Böbekler), Belönü (Ağlasun) adlarında iki nahiye ve 77 köy, Bucak kazasına bağlı Milli ve Kızılkaya nahiyeleri ile 29 köy ve Tefenni kazasına bağlı Gölhisar ve Dirmil nahiyeleri ile 57 köy bulunmaktadır 1926 yılı salnamesine göre Burdur vilayetinin erkek ve kadın olmak üzere toplam genel nüfusu 80.229 iken ${ }^{10}, 1929$ yılı devlet yıllığına göre 83.876’dır. Bu durumda 3 yıl içinde genel nüfusta 3.647 kişi

7 TC Devlet Salnamesi, 1927-1928, Matbuat Müdiriyyet-i Umumiyyesi, s. 746; 1914 yılı Konya Vilayet Salnamesi'ne göre, kuzey enleminin 37-38 dereceleriyle, doğu boylamının 27-28 dereceleri arasında bir mevkide bulunan Burdur kazası, 15.000 km² yüzölçümünde geniş bir araziye sahiptir. KVS, R. 1330, s. 353-354.

8 TC Devlet Salnamesi, 1926-1927, s. 733-734.

9 TC Devlet Salnamesi, 1927-1928, s. 746; Burdur vilayetinin günümüzde merkez ilçe dışında Bucak, Gölhisar, Tefenni, Yeşilova, Ağlasun, Çeltikçi, Altınyayla, Çavdır, Karamanlı ve Kemer adlarında 10 ilçesi bulunmaktadır. Metin Tuncel, "Burdur", TDVİA, C. 6, Türkiye Diyanet Vakfı Yayınları, İstanbul 1992, s. 429.

10 TC Devlet Salnamesi, 1925-1926, s. 534. 
yani $\% 4,54$ oranında artı̧̧ olduğu görülmektedir.

\section{Tarım}

Salnamelere bakıldığında Burdur'un ekonomisinin genel olarak tarıma dayandığı görülmektedir. 1926 yılı salnamesine göre Burdur, sahası dar olmakla beraber iyi ve verimli bir ziraat vilayetidir. Başlıca ziraat geliri çeşitli hububat ile afyon, gülyağı olup bunların birincisi kısmen diğerleri tamamen ihraç edilir ve memleketin genel servetini oluşturur. Teknik ve çağa uygun ziraat aletlerinden olarak vilayette 31 orak makinas1, 1 lokomobil ${ }^{11}, 3$ sabit motorlu traktör ve 13 tınaz $^{12}$ ile 3 teriyöz (?) vardır. Vilayet dâhilinde ziraata uygun 1.406 .979 dönüm arazi bulunmaktadır. Bu arazinin yıllık ekilen miktarından tahminen 28.042.775 kilo buğday, 3.547.844 kilo arpa, 207.900 kilo yulaf, 924.124 kilo mısır, 112.288 kilo darı, 535.520 kilo çavdar, 281.124 kilo burçak, 997.920 kilo fasulye, 20.546 kilo afyon, 32.000 kilo kenevir, 54.000 kilo mercimek, 297.000 kilo tütün, 26.000 kilo patates, 13.500 kilo susam, 21.500 kilo pancar, 71.675 kilo nohut, 38.880 kilo bakla, 131.400 kilo böğrülce, 45.500 kilo soğan, 15.000 kilo sarımsak, 120.000 kilo gül yaprağı ürünleri alınmaktadır.

Vilayet dâhilinde pamuk ve pirinç ziraatı henüz gelişmemiştir. Aynı zamanda bir Marsilya kiremit fabrikası ile bir çimento fabrikası yapılmıştır. Merkez vilayette motorla hareket eden bir ziraat aletleri imalathanesi ile bir haşhaş yağı fabrikası, iki adet hızar fabrikası, iki adet un fabrikası ve su ile hareket eden diğer iki un fabrikası olmak üzere toplamda sekiz fabrika bulunmaktadır. Vilayet dâhilinde yalnız bir ticaret odası vardır. Merkez vilayette çeşitli sermayeli 12 şirket vardır. 1924 yilında Isparta, Aydın ve Antalya vilayetlerine 2.350 .000 kıyye ${ }^{13}$ buğday, 1.293 .000 kiyye arpa, 50.000 kıyye fasulye, 45.000 kıyye burçak, 6.600 kıyye tereyağı, 8.000 kıyye peynir, 6.500 kıyye badem ve 200.000 kıyye yün yapağı sevk ve ihraç edilmiştir. Vaktiyle dışarıya 120.000 miskal $^{14}$ gül yağı çıkarken bu sene 25.000 miskal ihraç edilmiştir ${ }^{15}$.

1926 yılı salnamesine göre Tefenni kazası dâhilinde ziraat edilen arazi, tahmini olarak 400.000 dönüm olup, bundan 200.000 dönümü yıllık ekilerek diğer 200.000 dönümü de gelecek yıla nadas olarak bırakılmaktadır. Bu yıl alınan ürün 8.500.000 kilo buğday, 4.216 .800 kilo arpa, 4.000.000 kilo misır, 500.000 kilo çavdar, 50.000 kilo yulaf, 100.000 kilo burçak, 50.000 kilo nohud, 20.000 kilo mercimek, 120.000 kilo fasulye, 20.000 kilo kum darı, 300.000 kilo anason, 2.000 kilo afyon, 10.000 kilo tütün olup bundan mahalli ihtiyaçlar karşılandıktan sonra 1.500 .000

11 Lokomobil; tekerlekler üzerine konulmuş, bir aracı istenilen yere çekebilecek biçimde yapılmış, genel olarak buharla çalışan ulaşım aracıdır. Tarımda, harman makinelerini, sabanları ve sulama araçlarını yürütmede kullanılır. https://tr.wikipedia.org/wiki/Lokomobil (Erişim Tarihi: 27.03.2020).

12 Tinaz; savrulmak için hazırlanan dövülmüş ekin yığınıdır. Tınaz makinesi; Tınaz durumundaki ekinleri savurarak yabanc1 nesneleri ayıran makine https://tr.wiktionary.org/wiki/ t\%C4\%Blnaz\#T\%C3\%BCrk\%C3\%A7e (Erişim Tarihi: 27.03.2020); https://tr.wiktionary.org/wiki/ t\%C4\%BInaz_makinesi (Erişim Tarihi: 27.03.2020).

13 Kıyye; okka, 400 dirhemlik bir ağırlık ölçüsü. Şimdiki 1.282 gramın karşılığıdır. Ferit Devellioğlu, a.g.e., s. 621.

14 Miskal; 24 kıratlık bir ağırlık ölçüsüdür. Bir miskal 96 buğdaya eşittir. Bugünkü 4.5 gram karşılı̆̆ıdır. Altın, gümüş, mücevher vb şeylerin tartılmasında kullanılırdı. Ferit Devellioğlu, a.g.e., s. 780; Mehmet Zeki Pakalın, a.g.e., C. 2, s. 546.

TC Devlet Salnamesi, 1925-1926, s. 534-536. 
kilo buğday, 400.000 kilo arpa, 10.000 kilo tütün, 2.000 kilo afyon, 300.000 kilo anason İzmir ve Denizli'ye ihraç olunur ${ }^{16}$.

1927 yılı salnamesine göre Burdur vilayetinin bir milyon beş yüz küsur bin dönüm tahmin edilen zirai arazisinden 1926 yılında 210.000 dönüm buğday, 690.000 dönüm arpa, 6.800 dönüm haşhaş, 4.000 dönüm çavdar, 3.800 dönüm yulaf, 77.700 dönüm misır, 150 dönüm darı, 280 dönüm bakla, 22.260 dönüm fasulye, 900 dönüm böğrülce, 2.800 dönüm nohut, 340 dönüm mercimek, 6.800 dönüm burçak, 500 dönüm patates, 1.000 dönüm kendir, 100 dönüm tütün olmak üzere toplam 28.630 dönümü ekilebilip buna karş1lık gerçekleşen hasatlardan 21.000.000 kilo buğday, 6.900.000 kilo arpa, 528.000 kilo haşhaş, 100.000 kilo çavdar, 57.000 kilo yulaf, 1.540 .000 kilo mısır, 15.000 kilo darı, 54.000 kilo bakla, 271.200 kilo fasulye, 190.000 kilo böğrülce, 288.000 kilo nohut, 124.000 kilo mercimek, 1.040 .000 kilo burçak, 500.000 kilo patates, 150.000 kilo kendir elyafi $^{17}, 9.000$ kilo tütün üretilmiştir.

Ziraat usulü çoğu yerde halen kara sabanla devam etmekte ise de, bunun sağladığı sınırlı faydanın, mevcut hayatı devam ettirmeyeceği çiftçiler tarafından anlaşıldığından son zamanlarda pulluk ve traktörlerle ziraata önem verilmeye başlanmıştır. Teknik ve çağa uygun ziraat aletlerinden olarak vilayette 33 orak makinesi, 1 lokomobil, 4 sabit motorlu traktör ve 13 tınaz ile 3 teriyöz vardır. Böylece bir yıl içinde orak makinesi sayısında 2, traktör sayısında 1 artış olmuştur. Çeşitli cins ve ebatlarda vilayetin hemen her tarafında yayılmaya başlayan pulluklara karşın, karasabanların sayısı günden güne azalmıştır. Zirai sanayiden peynircilik, bağcılık ilkel bir halde ise de afyonculuk, kilcilik oldukça ilerlemiştir. Henüz deneme aşamasında bulunan tütüncülükte kayda değer bir oranda başarı görünmektedir ${ }^{18}$.

1928 y1lı salnamesine göre Burdur vilayetinin yüzölçümü tahminen $7500 \mathrm{~km}^{2}$ olup bunun $1.500 \mathrm{~km}^{2}$ si ekili, $6.000 \mathrm{~km}^{2}$ si de ekili değildir. Ekili olmayan arazinin $4.500 \mathrm{~km}^{2} \mathrm{si}$ dağlık, taşlık ve ormanlık, $1.000 \mathrm{~km}^{2} \mathrm{si}$ de göl ve bataklıktır. Geri kalanı ise meradır. Vilayetin bir senelik ekili alan miktarıyla hasatlar toplamı aşağıdaki gibidir. 
Tablo 1. 1927-1928 Devlet Salnamesine Göre Burdur Vilayetinin Ekili Alan Miktar1 ${ }^{19}$

\begin{tabular}{|c|c|c|c|c|c|c|c|c|c|c|c|c|}
\hline $\begin{array}{l}\text { Kazaların } \\
\text { İsimleri }\end{array}$ & $\begin{array}{l}\text { Buğday } \\
\text { Dönüm }\end{array}$ & $\begin{array}{l}\text { Arpa } \\
\text { Dönüm }\end{array}$ & $\begin{array}{l}\text { Yulaf } \\
\text { Dönüm }\end{array}$ & $\begin{array}{l}\text { Çavdar } \\
\text { Dönüm }\end{array}$ & $\begin{array}{l}\text { Burçak } \\
\text { Dönüm }\end{array}$ & $\begin{array}{l}\text { Mısır } \\
\text { Dönüm }\end{array}$ & $\begin{array}{l}\text { Ak Darı } \\
\text { Dönüm }\end{array}$ & $\begin{array}{l}\text { Bakla } \\
\text { Dönüm }\end{array}$ & $\begin{array}{l}\text { Patates } \\
\text { Dönüm }\end{array}$ & $\begin{array}{l}\text { Kenevir } \\
\text { Dönüm }\end{array}$ & $\begin{array}{l}\text { Üzüm Bağı } \\
\text { Asma } \\
\text { Dönüm }\end{array}$ & $\begin{array}{l}\text { Fasulye } \\
\text { Sâk }^{1}\end{array}$ \\
\hline $\begin{array}{l}\text { Burdur } \\
\text { Merkez } \\
\text { Kazası }\end{array}$ & 150.000 & 50.000 & 2.000 & 3.000 & 3.000 & 6.000 & 600 & 50 & 500 & 1.000 & 5.000 & 1.000 \\
\hline $\begin{array}{l}\text { Tefenni } \\
\text { Kazası }\end{array}$ & 110.000 & 40.000 & 600 & 1.500 & 4.000 & 12.000 & 100 & 50 & 100 & 200 & 2.300 & 200 \\
\hline $\begin{array}{l}\text { Bucak } \\
\text { Kazası }\end{array}$ & 350.000 & 65.000 & 300 & 0 & 2.000 & 5.000 & 2.500 & 300 & 0 & 50 & 3.000 & 600 \\
\hline Toplam & 610.000 & 155.000 & 2.900 & 4.500 & 9.000 & 23.000 & 3.200 & 400 & 600 & 1.250 & 10.300 & 1.800 \\
\hline
\end{tabular}

Tablo 2. 1927-1928 Devlet Salnamesine Göre Burdur Vilayetinin Üretilen Ürün Miktar120

\begin{tabular}{|c|c|c|c|c|c|c|c|c|c|c|c|c|}
\hline $\begin{array}{l}\text { Kazaların } \\
\text { İsimleri }\end{array}$ & $\begin{array}{l}\text { Buğday } \\
\text { Kilo }\end{array}$ & $\begin{array}{l}\text { Arpa } \\
\text { Kilo }\end{array}$ & $\begin{array}{l}\text { Yulaf } \\
\text { Kilo }\end{array}$ & $\begin{array}{l}\text { Çavdar } \\
\text { Kilo }\end{array}$ & $\begin{array}{l}\text { Burçak } \\
\text { Kilo }\end{array}$ & $\begin{array}{l}\text { Misır } \\
\text { Kilo }\end{array}$ & $\begin{array}{l}\text { Ak Darı } \\
\text { Kilo }\end{array}$ & $\begin{array}{l}\text { Bakla } \\
\text { Kilo }\end{array}$ & $\begin{array}{l}\text { Patates } \\
\text { Kilo }\end{array}$ & $\begin{array}{l}\text { Kenevir } \\
\text { Kilo }\end{array}$ & $\begin{array}{l}\text { Üzüm } \\
\text { Bağı } \\
\text { Asma } \\
\text { Kilo }\end{array}$ & $\begin{array}{c}\text { Fasulye } \\
\text { Kilo }\end{array}$ \\
\hline $\begin{array}{l}\text { Burdur } \\
\text { Merkez } \\
\text { Kazası }\end{array}$ & 7.500 .000 & 2.000 .000 & 800.000 & 250.000 & 24.000 & 750.000 & 52.000 & 15.000 & 300.000 & 40.000 & & 70.000 \\
\hline $\begin{array}{l}\text { Tefenni } \\
\text { Kazası }\end{array}$ & 5.500 .000 & 1.600 .000 & 200.000 & 100.000 & 32.000 & 1.200 .000 & 5.000 & 12.000 & 20.000 & 7.000 & 250.000 & 10.000 \\
\hline $\begin{array}{l}\text { Bucak } \\
\text { Kazası }\end{array}$ & 8.500 .000 & 2.500 .000 & 100.000 & 0 & 20.000 & 700.000 & 200.000 & 30.000 & 0 & 1.500 & 500.000 & 45.000 \\
\hline Yekûn & 21.500 .000 & 6.100 .000 & 1.100 .000 & 350.000 & 76.000 & 2.650 .000 & 257.000 & 57.000 & 320.000 & 48.500 & & 125.000 \\
\hline
\end{tabular}

\footnotetext{
19 TC Devlet Salnamesi, 1927-1928, s. 747.

20 TC Devlet Salnamesi, 1927-1928, s. 747.
} 
Tablo 1'e göre, Burdur vilayetinin ekili alanlarına baktığımız zaman birinci sırada 610.000 dönüm ile buğday, ikinci sırada 155.000 dönüm ile arpa, üçüncü sırada 23.000 dönüm ile mısır, dördüncü sırada ise 10.300 dönüm ile üzüm bağı asma yer almaktadır. Tablo 2'deki üretilen ürün miktarına bakarsak, ilk sırada 21.500.000 kilo ile buğday, ikinci sırada 6.100.000 kilo ile arpa, üçüncü sırada 3.250 .000 kilo ile üzüm bağ1 asma, dördüncü sırada ise 2.650.000 kilo ile mısır bulunmaktadır. Hem ekili alan miktarı hem de üretilen ürün miktarına göre Bucak kazası buğday, arpa, ak darı ve baklada, Tefenni kazası mısır ve burçakta, Burdur merkez kazası üzüm bağı asma, yulaf, çavdar, patates, kenevir ve fasulyede ilk sıradadır.

Tablo 3. 1928-1929 Devlet Y1llı̆̆ına Göre Burdur Vilayetinin Ekili Alan Miktar1²1

\begin{tabular}{|c|c|c|c|c|c|c|c|c|c|c|c|}
\hline Kazalar & $\begin{array}{l}\text { Buğday } \\
\text { Dönüm }\end{array}$ & $\begin{array}{l}\text { Arpa } \\
\text { Dönüm }\end{array}$ & $\begin{array}{l}\text { Yulaf } \\
\text { Dönüm }\end{array}$ & $\begin{array}{l}\text { Mısır } \\
\text { Dönüm }\end{array}$ & $\begin{array}{l}\text { Çavdar } \\
\text { Dönüm }\end{array}$ & $\begin{array}{l}\text { Bakla } \\
\text { Dönüm }\end{array}$ & $\begin{array}{l}\text { Ak Darı } \\
\text { Dönüm }\end{array}$ & $\begin{array}{l}\text { Fasulye } \\
\text { Dönüm }\end{array}$ & $\begin{array}{l}\text { Burçak } \\
\text { Dönüm }\end{array}$ & $\begin{array}{l}\text { Patates } \\
\text { Dönüm }\end{array}$ & $\begin{array}{l}\text { Kenevir } \\
\text { Dönüm }\end{array}$ \\
\hline Burdur & 170.000 & 60.000 & 2.000 & 9.000 & 3.000 & 0 & 400 & 2.000 & 8.000 & 600 & 1.000 \\
\hline Tefenni & 160.000 & 42.000 & 500 & 32.000 & 2.000 & 0 & 0 & 3.000 & 21.000 & 0 & 0 \\
\hline Bucak & 350.000 & 65.000 & 300 & 5.000 & 0 & 300 & 2.500 & 600 & 2.000 & 0 & 56 \\
\hline Genel Toplam & 680.000 & 167.000 & 2.800 & 46.000 & 5.000 & 300 & 2.900 & 5.600 & 31.000 & 600 & 1.056 \\
\hline
\end{tabular}

Tablo 3'e göre, Burdur vilayetinin ekili alanlarına baktığımız zaman birinci sırada 680.000 dönüm ile buğday, ikinci sırada 167.000 dönüm ile arpa, üçüncü sırada 46.000 dönüm ile mısır, dördüncü sırada ise 31.000 dönüm ile burçak yer almaktadır. Bir yıl öncesine göre bu ürünlerin ekili alan miktarında artış olduğu görülmektedir. 
Tablo 4. 1928-1929 Devlet Y1llığına Göre Burdur Vilayetinin Üretilen Ürün Miktar1²2

\begin{tabular}{|c|c|c|c|c|c|c|c|c|c|c|c|}
\hline Kazalar & $\begin{array}{l}\text { Buğday } \\
\text { Kilo }\end{array}$ & $\begin{array}{l}\text { Arpa } \\
\text { Kilo }\end{array}$ & $\begin{array}{l}\text { Yulaf } \\
\text { Kilo }\end{array}$ & $\begin{array}{l}\text { Misır } \\
\text { Kilo }\end{array}$ & $\begin{array}{l}\text { Çavdar } \\
\text { Kilo }\end{array}$ & $\begin{array}{l}\text { Bakla } \\
\text { Kilo }\end{array}$ & $\begin{array}{l}\text { Ak Darı } \\
\text { Kilo }\end{array}$ & $\begin{array}{l}\text { Fasulye } \\
\text { Kilo }\end{array}$ & $\begin{array}{l}\text { Burçak } \\
\text { Kilo }\end{array}$ & $\begin{array}{l}\text { Patates } \\
\text { Kilo }\end{array}$ & $\begin{array}{l}\text { Kenevir } \\
\text { Kilo }\end{array}$ \\
\hline Burdur & 7.500 .000 & 2.000 .000 & 800.000 & 750.000 & 250.000 & 15.000 & 50.000 & 300.000 & 24.000 & 300.000 & 40.000 \\
\hline Bucak & 8.500 .000 & 2.500 .000 & 100.000 & 700.000 & 0 & 30.000 & 200.000 & 45.000 & 20.000 & 0 & 1.500 \\
\hline $\begin{array}{l}\text { Umumî } \\
\text { Yekûn }\end{array}$ & 32.000 .000 & 9.000 .000 & 905.000 & 9.450 .000 & 450.000 & 45.000 & 250.000 & 367.000 & 844.000 & 300.000 & 41.500 \\
\hline
\end{tabular}

Tablo 4'deki üretilen ürün miktarına bakarsak, ilk sırada 32.000.000 kilo ile buğday, ikinci sırada 9.450.000 kilo ile mısır, üçüncü sırada 9.000.000 kilo ile arpa, dördüncü sırada ise 905.000 kilo ile yulaf bulunmaktadır. Bir yıl öncesine göre yulaf, bakla, patates, ak darı ve kenevir üretiminde düşüş olmakla beraber diğer ürünlerin üretiminde artış vardır.

“28 Teşrinievvel 1927 Umumi Nüfus Tahriri”ne göre ise Burdur vilayetinde 12 yaşından büyük erkeklerde zirai mesleklerin oranı \%73.43, kadınlarda \%51.05'dir. Kadın ve erkek toplamında, 12 yaşından büyük nüfusta zirai mesleklerin oranı \%60.80'dir ${ }^{23}$.

\section{Hayvancilık}

İklim şartları ve toprak özellikleri bakımından hayvancılığın gelişmesine elverişli bir yer olan Burdur'da hem büyükbaş, hem de küçükbaş hayvan yetiştirilmektedir ${ }^{24}$. 1927 y1lı salnamesine göre vilayet dâhilinde 1926 yılında sayılan 585 deve, 252 tiftik, 89.878 dişi kıl keçi, 21.191 erkek kı1 keçi, 31.812 dişi koyun, 5.872 erkek koyun ki toplam 109.690 baş ağnamdan başka, 2.145 kısrak $^{44}, 97$ iğdiç ${ }^{45}, 110$ aygır ${ }^{46}, 681$ at, 77 ester ${ }^{47}, 10.714$ merkeb $^{48}, 12.368$ dişi sığır, 14.201 erkek sığır, 1.600 dişi manda, 1.420 erkek manda olmak üzere toplam 43.413 baş evcil hayvan bulunmaktadır²5.

1928 y1lı salnamesine göre Burdur vilayetinde mevcut küçük ve büyükbaş hayvanlar ile hayvansal ürünler miktarı aşağıdaki tabloda gösterilmiştir.

22 Türkiye Cumhuriyeti Devlet Yıllı̆̆ı Matbuat Umum Müdürlüğü 1928-1929, s. 395.

2328 Teşrinievvel 1927 Umumi Nüfus Tahriri, Fasikül III, s. 26-27.

24 Yurt Ansiklopedisi, C. III, Anadolu Yayınc1lık, İstanbul 1982, s. 1542, 1570-1571; Mustafa Ali Uysal, Salnamelere Göre Burdur (1868-1914), Libra Kitapç11ık ve Yayınc1lık, İstanbul 2020, s. 229.

25 TC Devlet Salnamesi, 1926-1927, s. 736. 
Tablo 5. 1927-1928 Devlet Salnamesine Göre Burdur Vilayetinin Hayvan Sayıları ve Hayvansal Ürünleri ${ }^{26}$

\begin{tabular}{|c|c|c|c|c|c|c|c|c|c|c|c|c|c|}
\hline \multirow[b]{2}{*}{$\begin{array}{l}\text { Kazaların } \\
\text { İsimleri }\end{array}$} & \multicolumn{10}{|c|}{ Küçük ve Büyükbaş Hayvanlar } & \multicolumn{3}{|c|}{ Hayvansal Ürünler } \\
\hline & $\begin{array}{l}\text { Beygir } \\
\text { Baş }\end{array}$ & $\begin{array}{l}\text { Kısrak } \\
\text { Baş }\end{array}$ & $\begin{array}{l}\text { Merkep } \\
\text { Baş }\end{array}$ & $\begin{array}{l}\text { Katır } \\
\text { Baş }\end{array}$ & $\begin{array}{l}\text { Deve } \\
\text { Baş }\end{array}$ & $\begin{array}{l}\text { İnek } \\
\text { Baş }\end{array}$ & $\begin{array}{l}\text { Öküz } \\
\text { Baş }\end{array}$ & $\begin{array}{l}\text { Manda } \\
\text { Baş }\end{array}$ & $\begin{array}{l}\text { Koyun } \\
\text { Baş }\end{array}$ & $\begin{array}{l}\text { Keçi } \\
\text { Baş }\end{array}$ & $\begin{array}{l}\text { Süt } \\
\text { Kilo }\end{array}$ & $\begin{array}{l}\text { Yün ve } \\
\text { Yapağı } \\
\text { Kilo }\end{array}$ & $\begin{array}{l}\text { KeçiKıl } \\
\text { Kilo }\end{array}$ \\
\hline $\begin{array}{l}\text { Burdur } \\
\text { Kazası }\end{array}$ & 1.076 & 1.657 & 7.896 & 127 & 155 & 7.437 & 8.401 & 1.698 & 28.882 & 73.771 & 6.128.209 & 57.764 & 36.885 \\
\hline $\begin{array}{l}\text { Bucak } \\
\text { Kazası }\end{array}$ & 384 & 562 & 3.059 & 53 & 447 & 3.545 & 4.101 & 738 & 7.959 & 52.950 & 3.448 .950 & 15.918 & 26.475 \\
\hline $\begin{array}{l}\text { Tefenni } \\
\text { Kazası }\end{array}$ & 835 & 925 & 4.690 & 143 & 201 & 6.016 & 6.672 & 993 & 26.227 & 30.929 & 4.368 .785 & 52.654 & 15.114 \\
\hline Toplam & 2.295 & 3.144 & 15.645 & 323 & 803 & 16.998 & 19.176 & 3.429 & 63.068 & 157.650 & 13.945.944 & 126.336 & 78.474 \\
\hline
\end{tabular}

Tablo 5'e göre Burdur vilayetinde küçükbaş olarak en çok bulunan hayvan 157.650 baş ile keçidir. İkinci sırada 63.068 baş ile koyun bulunmaktadır. Büyükbaş hayvan olarak ilk sırada 19.176 baş ile öküz, ikinci sırada 16.998 baş ile inek, üçüncü sırada 15.645 baş ile merkep yer almaktadır. Diğer büyükbaş hayvanlar; manda, kısrak, beygir, deve ve katırdır. Hayvanlardan elde edilen ürünlere bakarsak, 13.945.944 kilo ile süt ilk sırada yer alırken, 126.336 kilo ile yün ve yapağı ikinci sırada, 78.474 kilo ile keçi kılı üçüncü sırada yer almaktadır. 
Tablo 6. 1928-1929 Devlet Y1llı̆̆ına Göre Burdur Vilayetinin Hayvan Sayıları ve Hayvansal Ürünleri²7

\begin{tabular}{|c|c|c|c|c|c|c|c|c|c|c|c|c|c|}
\hline \multirow{2}{*}{ Kazalar } & \multicolumn{10}{|c|}{ Küçük ve Büyükbaş Hayvanlar } & \multicolumn{3}{|c|}{ Hayvansal Ürünler } \\
\hline & $\begin{array}{l}\text { At } \\
\text { Baş }\end{array}$ & $\begin{array}{l}\text { Kısrak } \\
\text { Baş }\end{array}$ & $\begin{array}{l}\text { Merkep } \\
\text { Baş }\end{array}$ & $\begin{array}{l}\text { Katır } \\
\text { Baş }\end{array}$ & $\begin{array}{l}\text { Deve } \\
\text { Baş }\end{array}$ & $\begin{array}{l}\text { İnek } \\
\text { Baş }\end{array}$ & $\begin{array}{l}\text { Öküz } \\
\text { Baş }\end{array}$ & $\begin{array}{l}\text { Manda } \\
\text { Baş }\end{array}$ & $\begin{array}{l}\text { Koyun } \\
\text { Baş }\end{array}$ & $\begin{array}{l}\text { Keçi } \\
\text { Baş }\end{array}$ & $\begin{array}{l}\text { Süt } \\
\text { Kilo }\end{array}$ & $\begin{array}{l}\text { Yün ve } \\
\text { Yapağı } \\
\text { Kilo }\end{array}$ & $\begin{array}{l}\text { Keçi Kılı } \\
\text { Kilo }\end{array}$ \\
\hline Burdur & 943 & 1.817 & 8.747 & 159 & 184 & 8.269 & 10.863 & 2.270 & 30.482 & 84.019 & 6.128 .209 & 57.761 & 36.885 \\
\hline Tefenni & 621 & 922 & 5.525 & 46 & 260 & 7.444 & 7.606 & 1.104 & 23.658 & 37.685 & 4.368 .785 & 52.654 & 15.114 \\
\hline Bucak & 384 & 562 & 3.050 & 53 & 447 & 3.545 & 4.101 & 738 & 7.959 & 52.950 & 3.448 .950 & 15.918 & 26.475 \\
\hline $\begin{array}{l}\text { Genel } \\
\text { Toplam }\end{array}$ & 1.948 & 3.301 & 17.331 & 258 & 891 & 19.258 & 22.570 & 4.112 & 62.099 & 174.654 & 13.945 .944 & 126.336 & 78.474 \\
\hline
\end{tabular}

Tablo 6'ya göre Burdur vilayetinde küçükbaş olarak en çok bulunan hayvan 174.654 baş ile keçidir. İkinci sırada 62.099 baş ile koyun bulunmaktadır. Büyükbaş hayvan olarak ilk sırada 22.570 baş ile öküz, ikinci sırada 19.258 baş ile inek, üçüncü sırada 17.331 baş ile merkep yer almaktadır. Diğer büyükbaş hayvanlar; manda, kısrak, at, deve ve katırdır. Hayvanlardan elde edilen ürünlere bakarsak, 13.945 .944 kilo ile süt ilk sırada yer alırken, 126.336 kilo ile yün ve yapağı ikinci sırada, 78.474 kilo ile keçi kılı üçüncü sırada yer almaktadır. Bir yıl öncesine göre koyun, at ve katır sayılarında azalma olurken diğer hayvan sayılarında artış olmuştur. Hayvanlardan elde edilen ürünlerde ise değişiklik olmamıştır.

27 Türkiye Cumhuriyeti Devlet Yılllı̆g Matbuat Umum Müdürlüğü 1928-1929, s. 396. 
Keçi ve koyun gibi küçükbaş hayvanların çiftçiye faydası çok olduğu için tercih sebebi olmuştur. Çiftçiler (köylüler) bu hayvanların etinden, sütünden, yün ve kılından, yavrusundan ve gübresinden faydalanırlar. Büyükbaş hayvanlardan öküz ve inekler çift hayvanlarını oluşturduğu için tercih sebebi olmuştur. Köylünün suyunu, odununu, pazardan ihtiyacını getiren, orak ve çift tarlasına tohum nakleden merkepler köylünün eli ayağ1, her şeyidir ${ }^{28}$.

\section{Madencilik}

Burdur'un maden yatakları bakımından çok zengin olduğu ve dikkate değer bir madencilik faaliyeti görüldüğü söylenemez ${ }^{29}$. Ancak salnamelerde Burdur'da keşfedilmiş madenlerden bahsetmektedir. 1885 yılı Konya Vilayet Salnamesinde Çerçin köyünün güney yönündeki tepelerde demir, manganez ve krom madenlerinin, Gölhisar nahiyesinin Çam köyündeki Eşeler dağının birçok yerlerinde de bor, tunç, krom, manganez ve kükürt madenlerinin bulunduğu belirtilmektedir ${ }^{30}$. 1914 y1lı Konya Vilayet Salnamesinde Burdur kazası dağlarında kömür madenlerine, demir parçalarına ve granit izlerine tesadüf edildiği, Tefenni kazasındaki dağlarda krom madeni bulunduğu, Kargalı köyünün üstündeki dağda kömür madeni keşfedildiği ancak hiçbirinin işletilemediği anlatılmaktadır ${ }^{31}$.

1926 ve 1927 yılı devlet salnamelerinde madenler hakkında bilgi verilmemiştir. Ancak 1928 yılı devlet salnamesinde, yalnız Burdur merkez kazası dâhilinde Sultan Ere mevkiinde maden kömürü olduğu bilgisine yer verilmiştir ${ }^{32}$.

\section{Dokumacilık}

Dokumacılık Burdur'un en önemli geçim vasitalarından biridir ${ }^{33}$. Bu sanat, Isparta'ya bağlı Senirkent kazasından Burdur'a göç eden 200 hane tarafından getirilmiştir. Birinci Dünya Savaşı'na kadar yalnız yerel ihtiyaçları karşılarken, savaşın başlamasıyla komşu vilayetlerin ihtiyaçlarını da karşılamaya başlamıştır. Burdur'un önemli gelir kaynaklarından olan dokumacılık, Milli Mücadele'nin sonuna kadar bu durumunu korumuştur. Daha sonra dış ülkelerden ithalat başlayınca yerini halıcılığa bırakmıştır. İkinci Dünya Savaşı'nın başlamasıyla dokumacılık tekrar canlanmış ve Burdur dokumaları ülkenin her yerine gönderilmiştir ${ }^{34}$. 1940 yılı itibariyle 2.800 evde 3.466 tezgâh bulunmakta idi. İkinci Dünya Savaşı sonunda dokuma tezgâhlarının sayısı 1.300'e kadar düşmüştür ${ }^{35}$. 1948'li yıllarda sanayinin gelişmesi ve dokuma fabrikalarının kurulması sebebiyle el dokumasına ihtiyaç azalmış, dolayısıyla Burdur alaca dokumacılığı da eski önemini kaybetmiştir ${ }^{36}$.

28 Mehmet Necati-Rıza İsmail (Erdem), Burdur Vilayeti, Halkiyatı ve Harsiyatı, (Çoğaltan: A. Feyzi Bayraktar, Yayıma Hazırlayan: Şevkiye Kazan Nas), Mehmet Akif Ersoy Üniversitesi Yayınları, Ankara 2015, s. 199, 201.

29 Yurt Ansiklopedisi, C. III, s. 1540, 1572.

$30 \quad$ KVS, H. 1302, s. 145, 153-154.

$31 \quad$ KVS, R. 1330, s. 214, 219.

32 TC Devlet Salnamesi, 1927-1928, s. 748.

33 Kemal Saden, "Dokumacılık", Burdur, C. I, S. 1, Şubat 1939, s. 5.

34 Burdur, Burdur Valiliği Yayınları, İstanbul 1955, s. 31.

35 Osman Yalçın, Burdur, Özyürek Yayınları, İstanbul 1960, s. 20.

36 Rengin Oyman, "Burdur İli Geleneksel Dokumaları ve Günümüzdeki Durumu”, I. Burdur Sempozyumu, Bildiriler, 
Konya Vilayet Salnamelerine göre, Burdur' da her tür iplik alacas1 ${ }^{37}$, bez, kilim, seccade, hamam ve el havluları ile masa örtüleri dokunur ${ }^{38} .1883$ yılında 75, 1906 yılında 300 ve 1914 yılında 500 alaca tezgâhı bulunmaktadır ${ }^{39}$. Alacalar, havlular ve masa örtüleri tüccarlar tarafından satın alınarak İstanbul, İzmir, Konya, Antalya, Denizli, Akşehir, Ilgın, Karahisar ve Kütahya gibi yerlere satılmaktadır. Alacalar, entari ve her çeşit mefrûşât için en sağlam kumaşa tercih edilmektedir ${ }^{40}$. Ayrıca 1914 yılı itibariyle 30 peşgir ve havlu tezgâhı ile 60 kıldan çul, çuval ve torba dokuma tezgâhı vardır ${ }^{41}$. Dokutulan senelik 150.000 top alacanın bir kısmı komşu vilayetlere ihraç edilmekte, bir kısmı da kaza içinde kullanılmaktadır ${ }^{42} .1906$ yılında Burdur kazasında 100 halı tezgâhı bulunmakta, 500'den fazla işçi çalışmakta ve çok güzel halılar imal edilmekte idi³ ${ }^{43} 1914$ yılında halı tezgâhı sayısının arttığı, 8 y1l içinde 100'den 1000'e çıktığ görülmektedir ${ }^{44}$.

1926 yılı salnamesine göre Burdur vilayetinde ilkel olarak dokumacılık mevcuttur. Haftada 1.000 top dokuma imal edilmektedir. 25.000 lira sermayeli küçük bir dokuma şirketi kurulmuştur. Vilayette halıcılığa oldukça önem verilmekte ve 1926 yılı itibariyle 250 tezgâh işlemektedir. Y1lda içeriye ve dişarıya 60.000 arşın halı, 80.000 top alaca, 25.000 top bez sevk edilmektedir ${ }^{45}$.

1927 y1lı devlet salnamesine göre Burdur vilayetinin çoğu köylerinde kendir elyafından urgan, sicim, yular gibi maddeler imal edilir ve çevre vilayetlere ihraç olunur. Çul, kıl torba, kolan gibi eşya dokuyan ve ihracat yapan köyler de vardır. Tefenni’nin Bayındır ve Burdur'un Aziziye köylerinin yünden mamûl kilimleri meşhurdur. Keçecilik de bu sanat sahiplerini geçindirir haldedir. 1927 yıl1 devlet salnamesinde ayrıca, 600'e yakın tezgâh işleten alacacılığın günden güne ilerlemekte olduğu, halıcılığa da yakın zamanda daha çok heves ve rağbet uyandığı ve vilayetin çeşitli yerlerinde halı imal eden tezgâhların sayısının 1000'e yaklaştığı belirtilmektedir ${ }^{46}$. Bu tarihte Bucak kazasında ise 400'e yakın halı tezgâhı işlenmektedir ${ }^{47}$.

1928 yılı devlet salnamesine göre Burdur vilayetinde 500 alaca bez tezgâhında yılda 500.000 top alaca ile 600 halı tezgâhında ${ }^{48}$ yılda 55.000 metre kare halı dokutulmuştur. Şark Halı, Türk Varlı̆̆l, Nur Halı ve Karagözzâde Halı adlarında 4 halı şirketi vardır. Bunlardan Şark Halı'nın müdürü İtalyan,

Mehmet Akif Ersoy Üniversitesi Rektörlüğü, 16-19 Kasım 2005, Burdur, C. I, Fakülte Kitabevi Yayınları, Isparta 2007, s. 115.

37 Alacacılık işiyle uğraşanlara Çulha denirdi. Alaca dokuma işini evlerinde basit el tezgâhlarında yaparlardı. Renksiz, beyaz ve çizgisiz olanlara bez adı verilirdi. Bezler daha ucuzdu. Mehmet Necati-Rıza İsmail (Erdem), a.g.e., s. 208.

38 KVS, H. 1306, s. 175; KVS, H. 1309, s. 345.

39 KVS, H. 1300, s. 146; KVS, R. 1322, s. 131; KVS, R. 1330, s. 653.

$40 \quad K V S$, H. 1309, s. 345; KVS, H. 1301, s. 120.

$41 \quad K V S$, R. 1330, s. 653.

$42 \quad$ KVS, R. 1330, s. 490-491; Mustafa Ali Uysal, a.g.e., s. 235-236.

$43 \quad$ KVS, R. 1322, s. 307.

$44 \quad$ KVS, R. 1322, s. 131; KVS, R. 1330, s. 653.

45 TC Devlet Salnamesi, 1925-1926, s. 535.

46 TC Devlet Salnamesi, 1926-1927, s. 735-736.

47 TC Devlet Salnamesi, 1926-1927, s. 737.

48 Bu durumda 1906-1928 yılları arasında halı tezgâhı sayısının bazen arttı̆̆ı, bazen de azaldığı anlaşılmaktadır. 
e-ISSN 2458-7672

https://dergipark.org.tr/tr/pub/jhf

diğerleri Türk’tür ${ }^{49}$. Bu şirketlerin Bucak ve Tefenni kazaları ile Karamanlı köyünde ve diğer köylerde halı tezgâhları bulunmaktadır. Bu tezgâhlarda yılda 35.000 arşın halı dokunmakta ve İzmir'deki büyük şirketler vasıtasıyla Amerika'ya ve Avrupa'ya gönderilmektedir. Birçok aile evlerinde halı dokuyarak geçimlerini sağlamaktadır. Burdur' daki şirketler genel atölye açmamışlardır. Seccadeler, taban halıları, Amerika çeşidi, içi dolu şark tarzı ve göbekli gibi her çeşit halı dokunmakta ve büyük rağbet görmektedir ${ }^{50}$.

\section{Fabrikalar}

1926 yılı salnamesine göre Burdur vilayet merkezinde, daha önce tarımla ilgili bölümde bahsedildiği üzere toplam sekiz fabrika bulunmaktadır. Bunların 4 tanesi un fabrikası, 2 tanesi hızar fabrikası, biri ziraat aletleri imalathanesi ve biri de haşhaş yağı fabrikasıdır ${ }^{51} .1927$ yılı salnamesinde 1 kereste ve 4 un fabrikasıyla 8 adi un değirmeninden sözedilmiştir ${ }^{52}$. Burdur vilayetindeki fabrikalar hakkında en ayrıntılı bilgi 1928 yılı devlet salnamesinde yer almaktadır. 1928 yılı salnamesine göre Burdur vilayetinde bulunan fabrikalar ile cinsleri ve üretimi aşağıdaki tabloda gösterilmiştir.

49 TC Devlet Salnamesi, 1927-1928, s. 748.

50 Mehmet Necati-Rıza İsmail (Erdem), Burdur Vilayeti, Halkiyatı ve Harsiyatı, a.g.e., s. 207-208.

51 TC Devlet Salnamesi, 1925-1926, s. 535.

52 TC Devlet Salnamesi, 1926-1927, s. 733. 
Tablo 7. 1927-1928 Devlet Salnamesine Göre Burdur Vilayeti Merkezinde Bulunan Fabrikalar, Cinsleri ve Üretimi ${ }^{53}$

\begin{tabular}{|c|c|c|c|c|c|c|c|c|}
\hline \multirow{2}{*}{ Bulundukları Mahaller } & \multirow[b]{2}{*}{ İsimleri } & \multirow{2}{*}{$\begin{array}{l}\text { Ne İle } \\
\text { Uğraştıkları }\end{array}$} & \multirow[b]{2}{*}{ Türü } & \multicolumn{5}{|c|}{ Fabrika-Değirmenlerin } \\
\hline & & & & Sahiplerinin İsimleri & Tâbiiyyetleri & $\begin{array}{l}\text { Harekete } \\
\text { Geçiren } \\
\text { Kuvvetle- } \\
\text { rinin } \\
\text { Cinsleri }\end{array}$ & $\begin{array}{l}\text { Kaç Beygir } \\
\text { Kuvvetinde OI- } \\
\text { duğu }\end{array}$ & Bir Sene Zarfındaki Üretim \\
\hline $\begin{array}{l}\text { Burdur Kayapınar } \\
\text { Mevkiinde }\end{array}$ & Un ve Hizar & - & Fabrika & $\begin{array}{l}\text { Kabacalızâde Hacı } \\
\text { Abdurrahman Efendi }\end{array}$ & Türkiye Cumhuriyeti & Su & $\begin{array}{l}\text { On altı̧̧ar Beygir } \\
\text { Kuvvetinde }\end{array}$ & $\begin{array}{l}\text { Sekiz yüz bin kilo un, bin iki yüz metreküp } \\
\text { kereste }\end{array}$ \\
\hline “ & Un & - & “ & Velicanzâde Biraderler & “ & “ & “ & Sekiz yüz bin kilo un \\
\hline " & " & - & " & Baki Beyzâdeler & “ & " & " & " \\
\hline “ & “ & - & “ & Hacı Yavsızâdeler & " & “ & " & Dokuz yüz bin kilo un \\
\hline $\begin{array}{l}\text { Burdur Kurna Köyün- } \\
\text { de }\end{array}$ & Hizar & - & " & Tıkırdıkzâde Hacı Osman & “ & “ & Sekiz Beygir & Dokuz yüz metreküp kereste \\
\hline $\begin{array}{l}\text { Burdur'un llıca } \\
\text { Mevkiinde }\end{array}$ & $\begin{array}{l}\text { Kiremit ve } \\
\text { Tuğla }\end{array}$ & - & “ & Çilzâde Fahreddin Bey & “ & Buharla & Yirmi dört Beygir & $\begin{array}{l}950.000 \text { adet Marsilya cins kiremit ve } \\
\text { tuğla }\end{array}$ \\
\hline $\begin{array}{l}\text { Muhtelif Mahaller ve } \\
\text { Köylerde }\end{array}$ & Değirmen & - & Değirmen & Muhtelif & “ & Su ile & Dörder Beygir & Her biri 72.000 kilo un öğütür \\
\hline Vilayet Dâhilinde & Tezgâh & $\begin{array}{l}\text { Halı Tezgâh } \\
600\end{array}$ & - & $\begin{array}{l}\text { Şark Halı, Türk Varlığı, Nur } \\
\text { Halı, Karagözzâde Halı } \\
\text { Kumpanyası }\end{array}$ & $\begin{array}{l}\text { Şark Halı Müdürü } \\
\text { İtalya, diğerleri Türk }\end{array}$ & El İle & & 55.000 arşın murabbaı ${ }^{2}$ halı \\
\hline “ & Tezgâh & $\begin{array}{l}\text { Alaca Bez } \\
\text { Tezgâh } 500\end{array}$ & - & - & Türkiye Cumhuriyeti & “ & & 500.000 top \\
\hline " & Marangoz & - & - & - & “ & “ & & $\begin{array}{l}500 \text { takım ceviz tahtadan mamûl oda } \\
\text { takımı, masa ve kanepe sandalye vb }\end{array}$ \\
\hline Tefenni Kazası & - & Un öğütür & $\begin{array}{l}\text { Kırk altı adet } \\
\text { değirmen }\end{array}$ & Muhtelif & “ & $\mathrm{Su}$ & & $\begin{array}{l}\text { Her biri ortalama olarak yirmi beşer bin } \\
\text { kilo un öğütür }\end{array}$ \\
\hline Bucak Kazası & - & “ & $\begin{array}{l}\text { On yedi adet } \\
\text { değirmen }\end{array}$ & “ & “ & “ & & $\begin{array}{l}\text { Her biri ortalama olarak yedi bin kilo un } \\
\text { öğütür }\end{array}$ \\
\hline
\end{tabular}

53 TC Devlet Salnamesi, 1927-1928, s. 748. 
Tablo 7 de görüldüğü üzere, Burdur Kayapınar mevkiinde Kabacalıâde Hacı Abdurrahman Efendi’ye ait 16'şar beygir kuvvetinde un ve hızar fabrikaları ile Velicanzâde Biraderler, Baki Beyzâdeler ve Hacı Yavsızâdeler'e ait aynı beygir kuvvetinde, su ile çalışan birer un fabrikası bulunmaktadır. Bir yıl içinde en fazla üretim 900.000 kilo un ile Hacı Yavsızâdeler'e ait un fabrikasındadır. Burdur Kurna köyünde Tıkırdıkzâde Hacı Osman'a ait 8 beygir kuvvetinde hızar, Burdur'un Ilıca mevkiinde Çilzâde Fahreddin Bey'e ait 24 beygir kuvvetinde, buharla çalışan kiremit ve tuğla fabrikası, çeşitli mahaller ve köylerde 4'er beygir kuvvetinde, su ile çalışan, her biri 72.000 kilo un ögüten değirmenler vardır. Burdur vilayet merkezinde y1lda 31.597 metrekare halı üretimi yapan 600 halı tezgâhı, yılda 500.000 top alaca bez üretimi yapan tezgâh ile yılda 500 takım ceviz tahtadan mamûl oda takımı, masa, kanepe, sandalye vb. üretimi yapan marangoz mevcuttur. Tefenni kazasında su ile çalışan, yılda her biri ortalama olarak yirmi beşer bin kilo un ögüten 46 adet değirmen, Bucak kazasında da su ile çalışan, yılda her biri ortalama olarak yedi bin kilo un öğüten 17 adet değirmen bulunmaktadır.

\section{Bankalar}

1928 y1lı salnamesine göre Burdur vilayetinde bulunan bankalar aşağıdaki tabloda gösterilmiştir.

Tablo 8. 1927-1928 Devlet Salnamesine Göre Burdur Vilayetinde Bulunan Bankalar ${ }^{54}$

\begin{tabular}{|c|c|c|c|c|}
\hline \multirow[b]{2}{*}{$\begin{array}{l}\text { Bankaların İsimleriyle Bulundukları YerF } \\
\text { ler }\end{array}$} & \multirow[b]{2}{*}{ Merkezi } & \multicolumn{2}{|c|}{ Genel Sermayeler } & \multirow{2}{*}{$\begin{array}{l}\text { Şubenin Kuruluş } \\
\text { Tarihi }\end{array}$} \\
\hline & & $\begin{array}{l}\text { Miktarı } \\
\text { Lira Adet }\end{array}$ & Türü & \\
\hline Burdur Vilayeti Ziraat Bankası & \multirow{3}{*}{ Ankara } & - & Evrâk-ı Nakdiyye ${ }^{3}$ & 1305 \\
\hline Burdur Vilayeti Bucak Kazası Ziraat Bankası & & - & " & - \\
\hline $\begin{array}{l}\text { Burdur Vilayeti Tefenni Kazası Ziraat Ban- } \\
\text { kası }\end{array}$ & & - & " & 1325 \\
\hline
\end{tabular}

Tablo 8 de görüldüğü gibi Burdur vilayeti merkez kazasında, çiftçiye ve köylüye destek olan, Hicri 1305 (Miladi 1888) yılında kurulan Ziraat Bankası şubesi bulunmaktadır. Ayrıca Bucak ve Tefenni kazalarında da Ziraat Bankası vardır. Tefenni kazasında Hicri 1325 (Miladi 1907) yılında kurulmuş olan bankanın, Bucak kazasındaki kuruluş tarihi belirtilmemiştir. Burdur vilayetinde Ziraat Bankası dışında başka bir banka bulunmamaktadır.

\section{Genel, Özel ve Belediye Gelirleri}

1926 yılı salnamesine göre Burdur vilayetinin 1925 yılına ait bir y1llık genel geliri 535.431, özel geliri 175.078 lira olup belediyeler geliri de, merkez vilayetin 43.825 lira ve Oğuzhan (Bucak) nahiyesinin 2.585 lira, Belönü (Ağlasun) nahiyesinin 550, Sertaç (Kemer) nahiyesinin de 50 liradan ibarettir. Tefenni 
kazasının 1925 y1lı genel geliri 44.310 lira ve özel geliri 34.021 lira, belediye geliri 3.509 lira, Gölhisar nahiyesinin ise 475 liradır $^{55} .1927$ y1l salnamesine göre Burdur vilayetinin genel geliri 248.812 lira ve özel geliri 246.896 lira olup, Burdur Belediyesi'nin gelir ve giderleri de 1926 yılı bütçesinde 236.000 lira olarak tespit olunmuştur ${ }^{56}$.

1928 y1lı salnamesine göre Burdur vilayetinin genel geliri 284.743 lira, özel geliri de 392.939 lira olup, Burdur merkez kazası belediyesinin geliri 65.150 ve Tefenni kazası belediyesinin 7.710 ve Bucak kazası belediyesinin 6.659 ve Burdur vilayetine bağlı Çeltikçi nahiyesi belediyesinin 2.300 ve Belönü belediyesinin 700 ve Tefenni kazasına bağlı Karamanlı belediyesinin 8.879 ve Çavdır nahiyesi belediyesinin 2.403 ve Bucak kazasına bağlı Kızılkaya nahiyesinin 2.150 liradır $^{57} .1929$ yılı devlet yıllığına baktığımız zaman Burdur vilayetinin genel gelirinin, özel gelirinin, Burdur merkez kazası belediyesinin gelirinin, Tefenni kazasının ve Bucak kazası belediyesinin gelirinin bir önceki yıl ile aynı olduğu görülmektedir ${ }^{58}$.

\section{Devlet Yolları}

Burdur vilayetinde, kazalarıyla ve komşu vilayetlerle ulaşımı sağlamak amacıyla çeşitli uzunluklarda yollar yapılmıştır. 1927 yılı salnamesine göre Burdur vilayetinin devlet yolları, 25 kilometre uzunluğunda Burdur - Baladız istasyonu ve vilayet sınırına kadar 80 kilometre uzunluğunda Burdur - Antalya şoselerinden ibarettir. Özel yollardan 70 kilometre uzunluğunda Burdur - Tefenni yolu ile Tefenni - Çavdır, Tefenni - Karamanlı - Çardak istasyonu yollarıyla, Çine - Belönü ve 450 metrelik hastane yoluyla, Burdur Gölü'nde son bulan dört kilometrelik Cumhuriyet Caddesi, aynı şekilde vilayet yolları vardır ${ }^{59}$.

1928 yılı salnamesinde, Burdur vilayetinde bulunan yollar aşağıdaki tabloda gösterildiği gibidir.

Tablo 9. 1927-1928 Devlet Salnamesine Göre Burdur Vilayetinde Bulunan Yollar ${ }^{60}$

\begin{tabular}{|c|c|c|c|c|c|}
\hline \multirow[b]{2}{*}{$\begin{array}{l}\text { Yolun } \\
\text { Başlangıcı -Bitişi }\end{array}$} & \multirow[b]{2}{*}{$\begin{array}{l}\text { Yolun Uzun- } \\
\text { luğu } \\
\text { (Kilometre) }\end{array}$} & \multirow[b]{2}{*}{$\begin{array}{l}\text { Sağlam Kısmı } \\
\text { (Kilometre) }\end{array}$} & \multicolumn{2}{|c|}{ Tamire Muhtaç Kısmı } & \multirow{2}{*}{$\begin{array}{l}\text { Yeni İnşa Olunmakta } \\
\text { (Kilometre) }\end{array}$} \\
\hline & & & $\begin{array}{l}\text { Tamir Olun- } \\
\text { makta }\end{array}$ & $\begin{array}{l}\text { Tamire Baş- } \\
\text { lanmamış }\end{array}$ & \\
\hline Burdur - Baladız & $24+785$ & $24+785$ & & & \\
\hline Burdur - Antalya & $80+000$ & $75+000$ & $5+000$ & & \\
\hline Burdur - Tefenni & $70+000$ & $34+000$ & & & $36+000$ \\
\hline
\end{tabular}

Tablo 9'a göre, Burdur - Baladız, Burdur - Antalya ve Burdur - Tefenni yollarının uzunluğu 1927 y1lı salnamesinde belirtildiği gibidir. En uzun yol olan 80 kilometrelik Burdur - Antalya yolunun sağlam kısmı 75 kilometre olup, 5 kilometresi tamir olunmaktadır. Burdur - Tefenni yolunun ise 34 kilometresi sağlam olup, 36 kilometresi de yeni yapılmaktadır.

55 TC Devlet Salnamesi, 1925-1926, s. 535-536.

56 TC Devlet Salnamesi, 1926-1927, s. 736.

57 TC Devlet Salnamesi, 1927-1928, s. 750.

58 Türkiye Cumhuriyeti Devlet Yıllığı Matbuat Umum Müdürlüğü 1928-1929, s. 397.

59 TC Devlet Salnamesi, 1926-1927, s. 736.

60 TC Devlet Salnamesi, 1927-1928, s. 749. 
Tablo 10. 1928-1929 Devlet Y1llığına Göre Burdur Vilayetinde Bulunan Yollar ${ }^{61}$

\begin{tabular}{|l|l|l|}
\hline Yolun & $\begin{array}{l}\text { Yolun Uzunluğu } \\
\text { Kaşlangıcı -Bitişi }\end{array}$ & $\begin{array}{l}\text { Sağlam Kısmı } \\
\text { Kilometre }\end{array}$ \\
\hline Burdur - Baladız & $24+785$ & $20+253$ \\
\hline Burdur - Antalya & $105+000$ & $100+000$ \\
\hline Burdur - Tefenni & $70+000$ & $34+000$ \\
\hline
\end{tabular}

Tablo 10’a baktığımız zaman bir önceki yıla göre Burdur - Antalya yolunda 25 kilometrelik artış vardır. Dolayısıyla yine en uzun yol 105 kilometrelik uzunluğuyla Burdur - Antalya yoludur. Diğer yolların uzunluğunda bir değişiklik yoktur. Burdur - Tefenni yolunun sağlam kısmında bir değişme olmazken Burdur - Baladız yolunun sağlam kısmında yaklaşık 4.5 kilometrelik azalma, Burdur - Antalya yolunun sağlam kısmında ise 25 kilometrelik artış vardır.

\section{Sonuç}

$\mathrm{Bu}$ çalışmada Cumhuriyet döneminde yayınlanan ilk devlet salnamelerinden (yıllıklarından) yararlanarak Burdur vilayetinin ekonomik durumu hakkında 1925-1929 yıllarını kapsayacak şekilde istatistiki bilgiler verilmiştir. Salnamelere göre Burdur'un ekonomisi genel olarak tarım ve hayvancılığa dayanmaktadır. Verimli topraklara sahip olan Burdur'un başlıca ziraat geliri çeşitli hububat, afyon ve gülyağıdır. Teknik ve çağa uygun ziraat aletleri kullanılmaktadır. 1925-1929 yılları arasında Burdur vilayetinin ekili alanlarına ve üretilen ürün miktarına baktığımız zaman birinci sırada buğday yer almaktadır. Diğer başlıca ürünler ise arpa, mısır, çavdar, yulaf, burçak ve üzüm bağıdır. 12 yaşından büyük nüfusta zirai mesleklerin oranı \%60.80'dir.

Hayvancılığın gelişmesi açısından elverişli bir konumda olan Burdur'da hem büyükbaş, hem de küçükbaş hayvan yetiştirilmektedir. Burdur vilayetinde küçükbaş hayvan olarak en çok keçi, ikinci sırada koyun bulunmaktadır. Büyükbaş hayvan olarak ilk sırada öküz, ikinci sırada inek, üçüncü sırada merkep yer almaktadır. Hayvansal ürün olarak ilk sırada süt yer alırken, ikinci sırada yün ve yapağı, üçüncü sırada keçi k11 yer almaktadır.

1928 yılı devlet salnamesinde, yalnız Burdur merkez kazası dâhilinde Sultan Ere mevkiinde maden kömürü olduğu söylenmektedir. Dolayısıyla Burdur'da dikkate değer bir madencilik faaliyeti görülmemektedir. Dokumacılık ve halıcılık gibi sanat dalları, Burdur'un en önemli geçim vasıtalarından ve gelir kaynaklarındandır. Salnamelerde alaca dokumacılığının günden güne ilerlemekte olduğu, halıcılığa da yakın zamanda daha çok heves ve rağbet uyandığı ve vilayetin çeşitli yerlerinde halı imal eden tezgâhların sayısının 1000'e yaklaştığı belirtilmektedir. Burdur vilayetinde 4 halı şirketi vasıtasıyla her çeşit halı dokunmakta ve büyük rağbet gören halılar Amerika ve Avrupa’ya da gönderilmektedir.

61 Türkiye Cumhuriyeti Devlet Y1llı̆̆1 Matbuat Umum Müdürlüğü 1928-1929, s. 397. 
Devlet salnamelerine göre Burdur vilayetinde en çok un fabrikaları bulunmaktadır. Bunun yanında hızar ve kereste fabrikası, ziraat aletleri imalathanesi, haşhaş yağı fabrikası, kiremit ve tuğla fabrikası, değirmenler ile halı ve alaca bez tezgâhları vardır.

Burdur vilayeti merkez kazasında, Tefenni kazasında ve Bucak kazasında Ziraat Bankası'nın birer şubesi bulunmaktadır. Burdur vilayetinde başka bir banka bulunmamaktadır. Burdur vilayetinin 1925 y1lına ait bir y1llık genel geliri 535.431 lira iken 1927 yılı genel geliri azalarak 284.743 lira olmuştur. 1925 y1lına ait özel geliri ise 175.078 lira iken 1927 y1lında artarak 392.939 lira olmuştur.

Salnamelerde ayrıca Burdur vilayetinin, kazalarıyla ve komşu vilayetlerle ulaşımını sağlamak amacıyla yapılan yolların sağlam kısımlarının ve tamir olunmakta olan kısımlarının uzunlukları hakkında da bilgi bulunmaktadır. Buna göre en uzun yol Burdur-Antalya yoludur.

\section{Kaynakça}

\section{Salname Ve Yillıklar}

Konya Vilayet Salnamesi (KVS): Hicri 1300, 1301, 1302, 1306, 1309, Rumi 1322, Rumi 1330.

TC Devlet Salnamesi, 1925-1926, Matbaa-i Âmire, İstanbul 1926.

TC Devlet Salnamesi, 1926-1927, Matbuat Müdiriyyet-i Umumiyyesi.

TC Devlet Salnamesi, 1927-1928, Matbuat Müdiriyyet-i Umumiyyesi.

Türkiye Cumhuriyeti Devlet Yıllığı Matbuat Umum Müdürlüğü 1928-1929, Devlet Matbaas1, İstanbul 1929.

\section{Araştırma Ve İnceleme Eserleri}

28 Teşrinievvel 1927 Umumi Nüfus Tahriri, Fasikül III, Ankara: Başvekâlet Müdevvenat Matbaası, 1929.

Aydın, Bilgin, “Salname”, TDVIA, C. 36, Türkiye Diyanet Vakfı Yayınları, İstanbul 2009, s. 51-54.

Burdur, Burdur Valiliği Yayınları, İstanbul 1955.

Devellioğlu, Ferit, Osmanlıca-Türkçe Ansiklopedik Lûgat, Aydın Kitabevi Yayınları, Ankara 1990.

İzgöer, Ahmet Zeki, (2005). “Osmanlı Salnâmelerinin Şehir Tarihi Bakımından Önemi”, Türkiye Araştırmaları Literatür Dergisi, C. 3, S. 6, 2005, s. 539-552.

İslam Ansiklopedisi (1949). “Salname”, X, İstanbul: Milli Eğitim Bakanlığı Yayınları, 134-135.

Mehmet Necati-Rıza İsmail (Erdem), Burdur Vilayeti, Halkiyatı ve Harsiyatı, (Çoğaltan: A. Feyzi Bayraktar, Yayıma Hazırlayan: Şevkiye Kazan Nas), Mehmet Akif Ersoy Üniversitesi Yayınları, Ankara 2015. 
Oyman, Rengin, "Burdur İli Geleneksel Dokumaları ve Günümüzdeki Durumu", I. Burdur Sетроzуити, Bildiriler, Mehmet Akif Ersoy Üniversitesi Rektörlüğ̈̈, 16-19 Kasım 2005, Burdur, C. I, Fakülte Kitabevi Yayınları, Isparta 2007, s. 112-122.

Pakalın, Mehmet Zeki, Osmanlı Tarih Deyimleri ve Terimleri Sözlüğü, C. III, Milli Eğitim Bakanlığı Yayınları, İstanbul 1971.

Pakalın, Mehmet Zeki, Osmanlı Tarih Deyimleri ve Terimleri Sözlüğ̈̈, C. 2, Milli Eğitim Basımevi, İstanbul 1983.

Saden, Kemal, "Dokumacılık”, Burdur, C. I, S. 1, Şubat 1939, s. 5.

Sertoğlu, Midhat, Osmanlı Tarih Lûgatı, Enderun Kitabevi Yayınları, İstanbul 1986.

Sütçü, Tevfik, "Sosyal Bilimlerde Araştırma Kaynağı Olarak Almanaklar, Sâlnâmeler ve Yıllıklar", İlmi Araştırmalar, S. 18, 2004, s. 79-92.

Tuncel, Metin, "Burdur", TDVIAA, C. 6, Türkiye Diyanet Vakfi Yayınları, İstanbul 1992, s. 426-429.

Uysal, Mustafa Ali, Salnamelere Göre Burdur (1868-1914), Libra Kitapçılık ve Yayıncıllk, İstanbul 2020.

Yalçın, Osman, Burdur, Özyürek Yayınları, İstanbul 1960.

Yurt Ansiklopedisi, C. III, Anadolu Yayınc1lı, İstanbul 1982.

\section{Web Siteleri}

http://ktp.isam.org.tr/salname/sayilar.php?sidno=D02467 (Erişim Tarihi: 27.02.2020).

https://tr.wiktionary.org/wiki/t\%C4\%B1naz\#T\%C3\%BCrk\%C3\%A7e(Erişim Tarihi: 27.03.2020).

https://tr.wiktionary.org/wiki/t\%C4\%B1naz_makinesi (Erişim Tarihi: 27.03.2020).

https://tr.wikipedia.org/wiki/Lokomobil (Erişim Tarihi: 27.03.2020).

https://www.tkgm.gov.tr/sites/default/files/icerik/ekleri/953.pdf (Erişim Tarihi: 23.04.2020).

(Tablolar içinde kullanılan Dipnotlar)

1 Sâk; sap demektir. Ferit Devellioğlu, a.g.e., s. 1097.

2 Arşın murabbaını metrekareye çevirmek için 0.5745 ile çarpmak gerekir. Bu durumda 55.000 arşın murabba1 31.597 metrekare yapar. https://www.tkgm.gov.tr/sites/default/files/icerik/ekleri/953.pdf (Erişim Tarihi: 23.04.2020).

3 Evrâk-1 Nakdiyye, kâğıt paralar demektir. Ferit Devellioğlu, a.g.e., s. 289. 